\title{
Analysis of radiographic images and germination of Campomanesia pubescens (Mart. ex DC.) O.Berg (Myrtaceae Juss.) seeds under drying
}

\author{
E. V. E. J. Amaral (D), J. F. Sales $^{a *}$ (D), J. Zuchi ${ }^{b}$ (D), J. M. G. Neves ${ }^{c}$ (D) \\ and J. A. Oliveira ${ }^{d}$ (D) \\ anstituto Federal de Educação, Ciência e Tecnologia Goiano - IFGoiano, Campus Rio Verde, Rod. Sul Goiânia, Km 01, \\ Zona Rural, CEP 75901-970, Rio Verde, GO, Brasil \\ 'Instituto Federal de Educação, Ciência e Tecnologia Goiano - IFGoiano, Polo de Inovação, Rede Arco Norte, Campus Rio \\ Verde, Rod. Sul Goiana, Km 01, Zona Rural, CEP 75901-970, Rio Verde, GO, Brasil \\ 'Instituto Federal de Educação, Ciência e Tecnologia do Norte de Minas Gerais - IF Norte de Minas, Rua Professor \\ Monteiro Fonseca, 216, Vila Brasília, CEP 39400-140, Montes Claros, MG, Brasil \\ ¿Universidade Federal de Lavras - UFLA, Campus Universitário, CP 3037, CEP 37200-000, Lavras, MG, Brasil \\ *e-mail: juliana.sales@ifgoiano.edu.br
}

Received: February 14, 2019 - Accepted: August 6, 2019 - Distributed: November 30, 2020

(With 3 figures)

\begin{abstract}
The objective of this study was to evaluate the internal morphology of seeds of Campomanesia pubescens (Mart. ex DC.) $\mathrm{O}$. Berg with varying water content through X-ray image analysis, and correlate the images with the germination of these seeds. Fruits were collected in Jataí, Goiás, Brazil, and taken to the Seed Laboratory of the Federal Institute Goiano, Rio Verde Campus, where they were processed and the seeds were extracted. To establish the predetermined water content $(43 \%, 37 \%, 34 \%, 31 \%$, and $28 \%$ wet basis), seeds with an initial water content of $43 \%$ were kept in an oven with forced air circulation at a temperature of $40{ }^{\circ} \mathrm{C}$ until they reached the predetermined water content levels. Next, the seeds were placed in acrylic holders with double-sided tape and transported to the Federal University of Lavras (UFLA), where they were exposed to different intensities of radiation. The X-ray test was conducted with 200 seeds per treatment, and images of the internal structures of the seeds were evaluated. The seeds were returned to the Seed Laboratory of the Federal Institute Goiano, Rio Verde Campus, where the germination test was initiated. The experimental design was completely randomized, in a factorial design $(5 \times 4)$, in which there were five water content levels and four seed classes, with four replications. The X-ray test was efficient in the identification of filled, malformed, damaged and empty seeds, which germination rate above $50 \%$ in the filled seeds. This visualization of the internal morphology of the seed can be useful to select seeds of better quality, improving the percentage of germination of $C$. pubescens seeds.
\end{abstract}

Keywords: gabirobeira, X-ray test, quality.

\section{Análise de imagens radiográficas e germinação de sementes de Campomanesia pubescens (Mart. ex DC.) O.Berg (Myrtaceae Juss.) sob secagem}

\section{Resumo}

O objetivo deste trabalho foi avaliar a morfologia interna de sementes de Campomanesia pubescens (Mart. ex DC.) O.Berg com diferentes teores de água por meio de análise de imagens de raios-X, e correlacionar as imagens com a germinação dessas sementes. Os frutos foram coletados no município de Jataí, Goiás, Brasil, e levados ao Laboratório de Sementes do Instituto Federal Goiano, Campus Rio Verde, onde foram processados e as sementes foram extraídas. Para estabelecer o teor de água predeterminado $(43 \%, 37 \%, 34 \%, 31 \%$ e $28 \%$ base úmida), as sementes com um teor inicial de água de $43 \%$ foram mantidas em estufa com circulação de ar induzida, a uma temperatura de $40{ }^{\circ} \mathrm{C}$ até atingirem os níveis de conteúdo de água predeterminados. Em seguida, as sementes foram colocadas em suportes acrílicos com fita dupla face e transportadas para a Universidade Federal de Lavras (UFLA), onde foram expostas a diferentes intensidades de radiação. $\mathrm{O}$ teste de raios-X foi realizado com 200 sementes por tratamento, e imagens das estruturas internas das sementes foram avaliadas. As sementes foram devolvidas ao Laboratório de Sementes do Instituto Federal Goiano, Campus Rio Verde, onde foi iniciado o teste de germinação. O delineamento experimental 
foi inteiramente casualizado, em esquema fatorial $(5 \times 4)$, no qual foram encontrados cinco níveis de umidade e quatro classes de sementes, com quatro repetições. $\mathrm{O}$ teste de raios-X foi eficiente na identificação de sementes preenchidas, malformadas, danificadas e vazias, com taxas de germinação acima dos 50\% nas sementes cheias. Essa visualização das morfologia interna da semente pode ser útil para selecionar sementes de melhor qualidade, melhorando a porcentagem de germinação das sementes de C. pubescens.

Palavras-chave: gabiroba, teste de raios-X, qualidade.

\section{Introduction}

The Myrtaceae family consists of 23 genera and 1,029 species, of these, 790 are endemic to Brazil. The genus Campomanesia stands out with 39 species distributed in almost every national territory, of which 29 are endemic (Sobral et al., 2015). The species Campomanesia pubescens (Mart. ex DC.) O.Berg, is locally known as gabirobeira. It is endemic to Brazil, and is found throughout the Midwestern state and in some northern, northeastern, southeastern, and southern states (Sobral et al., 2015).

Has great potential for cultivation in new areas, since they are not very demanding on soil besides they present special flavors, with great concentration of sugars, proteins, vitamins, minerals and fibers (Martins et al., 2015), have medicinal characteristics (Dousseau et al., 2011). Besides it presents fruits with potential to revegetate areas contaminated with oily residues and their fruits are very appreciated by the fauna (Gogosz et al., 2010).

Dehydration of seeds is an important factor because desiccation tolerance allows for the expansion of the period during which seeds can be used following the time they were produced, contributing to the conservation of the species (Barbedo et al., 2002). Thus, it is essential to understand vital processes, such as the germination process and the degree of tolerance to dehydration (Marcos Filho, 2005).

Several authors have classified the seeds of species of the Campomanesia genus as recalcitrant (Dresch et al., 2012; Scalon et al., 2009; Melchior et al., 2006; Santos et al., 2004) because, in addition to being sensitive to desiccation, they do not tolerate storage at low temperatures owing to the formation of ice crystals within cells and the consequent loss of seed viability. Therefore, it is necessary to understand processes that assist in maximizing the quality of batches of seeds to be sown, thus homogenizing germination rates.

During some stages of seed processing, mechanical damage may occur, and the assessment of internal morphology is a basic requirement to identify problems associated with the physiological potential of the seeds, and serves both as support for quality control programs and for the elucidation of questions regarding abnormal seedlings and the presence of non-germinated seeds (Lima et al., 2013). There is also an increasing concern regarding the maintenance of the genetic variability of native species with a wide application spectrum and that are affected by the loss of their natural habitat and by uncontrolled extraction (Cota et al., 2012).

The X-ray test for seeds was first used in 1953 in Sweden by Simak and Gustafsson, it has since been improved and is considered a rapid and non-destructive method because it can be used to ascertain the occurrence of empty and poorly formed seeds, which can influence the results of germination, it has been recommended since the 1980s by the International Seed Testing Association (Garay et al., 2009).

This method consists of exposing the seeds to a low energy X-ray source and a photosensitive film. By penetrating the seeds and reaching the film, the rays allow the formation of a latent image, characterized by different degrees of light and shade. The principle of the technique is defined by X-ray absorption in various levels by the seed tissues, because of its structure, composition and density, in addition to the radiation exposure time (Silva et al., 2013). In this sense, the use of X-ray tests is of great value for a large number of species, being a non-destructive and fast test of direct application in the identification of internal damage of seeds and in the selection of the best quality seed batches (Carvalho et al., 2009).

Thus, the objective of this study was to evaluate the internal morphology of seeds of $C$. pubescens, with varying water content by analyzing radiographic images and correlating these images with the germination of these seeds.

\section{Material and Methods}

The fruits of $C$. pubescens were collected from approximately 50 plants in early November 2014 from a farm located in the county of Jataí, Goiás, Brazil $\left(18^{\circ} 12^{\prime} 10^{\prime \prime} \mathrm{S}\right.$ and $51^{\circ} 44^{\prime} 51^{\prime \prime} \mathrm{W}$ ) and taken to the Seed Laboratory of the Federal Institute Goiano, Rio Verde Campus, where they were processed and the seeds were extracted. The seeds were immersed in a $25 \%$ ammonium hydroxide solution $\left(\mathrm{NH}_{4} \mathrm{OH}\right)(1 \mathrm{~mL}$ of solution per $100 \mathrm{~mL}$ of macerated seeds) for $48 \mathrm{~h}$ (Carmona et al., 1994), and were then washed in running water to remove the mucilage.

To establish the predetermined water contents $(43 \%$, $37 \%, 34 \%, 31 \%$, and $28 \%$ wet basis), the seeds with initial water content $(43 \%)$ were kept in an oven with forced air circulation at a temperature of $40{ }^{\circ} \mathrm{C}$ until they reached the water content levels. The reduction of water content of the seeds was followed by water mass loss. Seeds were weighed periodically on an analytical balance with resolution of $0.001 \mathrm{~g}$, and the final weight was calculated using the following Formula 1:

$$
f W=i W \cdot\left(\frac{100-i W C}{100-f W C}\right)
$$


in which: $\mathrm{fW}=$ final weight of the sample $(\mathrm{g}) ; \mathrm{iW}=$ initial weight of the sample $(\mathrm{g})$; iWC = initial water content of the seeds (\%wet basis); fWC $=$ desired water content $(\%$ wet basis). Water content was determined using 15 seeds at $130{ }^{\circ} \mathrm{C}$ for four hours (h) in an oven with forced air circulation, adapted from Brasil (2009).

Next, the seeds were placed in acrylic holders with double-sided tape and transported to the Laboratory of Forest Seeds of the Department of Forest Sciences of the Federal University of Lavras (UFLA), MG, where they were exposed to different radiation intensities $(10,25,35,45,50$, and $60 \mathrm{KV})$ in an X-ray machine (Faxitron MX20) with exposure times of 10, 20, 30, 40, $50,60,70$, and up to 360 seconds. The standard of specific $\mathrm{X}$-rays was the one that allowed clear visualization of seed morphology. The images were saved on CDs for later analysis.

The X-ray test was conducted with 200 seeds from each treatment. Seeds with different water content were evaluated to obtain the images of the internal structures of the seeds and to assess possible natural damage. Seeds were arranged in the acrylic holders so as to allow better visualization of the embryo and of the empty internal spaces within the seeds.

After exposure to radiation, the seeds were removed from the plates, maintaining the numerical sequence, and were sent to the Seed Laboratory of the Federal Institute Goiano, Rio Verde Campus where the germination test was initiated. Seeds were sown in transparent plastic boxes (gerbox), on two sheets of blotter paper previously moistened with distilled water (Brasil, 2009) containing individualized and numbered cells, allowing the seed identification and their respective image. They were set to germinate in a Biochemical Oxygen Demand (B.O.D.) type germination chamber with $40 \%$ average relative humidity and an automatic photoperiod of $12 \mathrm{~h}$ light.

The effect of different water content and internal morphology classes were evaluated by the germination test. On day 14, the number of seeds with root protrusion was counted, and this criteria was used to assess germination.
The data were expressed as the percentage of germinated seeds (adapted from Brasil, 2009).

The experimental design was completely randomized, in a factorial design $(5 \times 4)$, in which there were five water contents and four seed classes, with four replications of 50 seeds. The quantitative data were submitted to homogeneity (Levene test) and error normality (Shapiro-Wilk test) evaluations, followed by ANOVA and mean comparisons via Tukey's test $(\mathrm{P}<0.05)$ using the Genes software (Cruz, 2013).

\section{Results and Discussion}

The analysis of the X-ray images allowed the internal morphology of C. pubescens seeds to be observed and the identification of the following seed classes: filled seeds (A) with their embryonic cavities fully filled, and with their embryos and cotyledons well formed; malformed seeds (B) with their embryonic cavities not fully filled, and with their embryos and/or cotyledons malformed; damaged seeds (C) with some mechanical damage to their structure (broken or cracked); and empty seeds (D), with their embryonic cavity empty (Figure 1).

Even so, the seeds of all classes were submitted to the germination test, for the validation of the classes of seeds used. The use of the X-ray image analysis technique is promising in that it may assist with the selection of high quality seeds and the seedling formation process (Lima et al., 2013; Pinto et al., 2012).

The radiation intensity that provided the clearest visualization of the images of C. pubescens was $18 \mathrm{Kv}$ and the most appropriate exposure time was approximately $10 \mathrm{~s}$. For seeds of Eugenia pleurantha O.Berg (Myrtaceae), the best combination was determined to be $50 \mathrm{Kv}$ for $60 \mathrm{~s}$ in a similar device (Masetto et al., 2007), showing that the radiation intensity and the exposure time differs among species and may vary depending on the brand and model of the device used.

$\mathrm{X}$-ray analyses revealed that most of the seeds were in the class of filled seeds, with well-formed embryos. This was followed by malformed seeds and a small number of
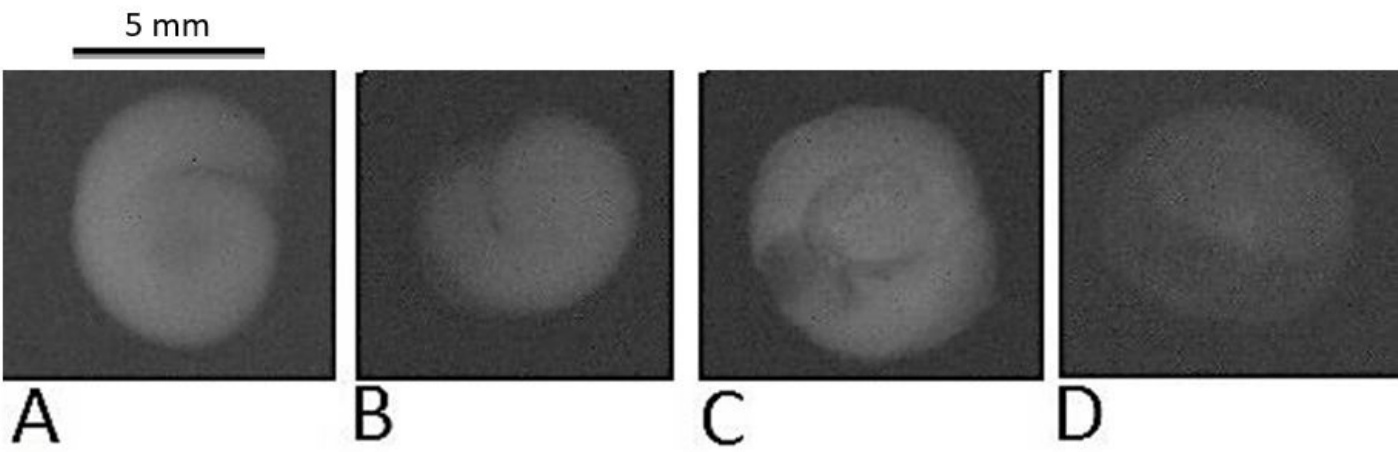

Figure 1. Classes of seeds of Campomanesia pubescens (DC.) O. Berg (Myrtaceae), obtained by radiographic images analysis. Filled seeds (A); malformed seeds (B); damaged seeds (C); and empty seeds (D). 
damaged and empty seeds. In seeds with a water content of $28 \%$, the proportion of malformed seeds was higher than filled seeds, indicating an effect of water content because they are recalcitrant seeds. When one of the internal seed structures was not complete, the chances of the formation of either low-vigor seedlings or no seedlings increases (Nunes et al., 2014).

Muxfeldt et al. (2012) also found a higher percentage of seeds with internal voids or malformations in desiccated seeds of Cryptocarpa aschersoniana Mez (Lauraceae); however, this characteristic did not result in reduced germination, as observed in this study. This can be explained by the deleterious effects that drying could have caused to the internal morphology of the seeds, which can also be seen in the different percentage of filled seeds among the various water contents (Table 1).

We observed that filled seeds exhibited a high percentage of germination, except for water contents of $37 \%$ and $28 \%$, in which germination was less than $50 \%$ (Table 2). These results are similar to those found by Amaral et al. (2011), where most seeds with completely filled embryonic cavities, or with more than $50 \%$ filled cavities, produced normal seedlings. Thus, we can state that filled seeds of C. pubescens, or those without internal empty spaces, are of good physiological quality and are adequate to obtain a high degree of batch homogeneity.

In the malformed seeds with water content of $28 \%$, the germination percentage was higher than that of filled seeds (Table 2). Van der Burg et al. (1994) affirmed that the existence of filled seeds that are not able to germinate might be caused by the presence of characteristics that are invisible to the X-ray test, such as infection by microorganisms or complete decay.

Most malformed seeds germinated because their malformation was less restrictive (Figure 2A); however, in some cases, when the malformation was close to $50 \%$ of the total seed (Figure 2B), germination did not occur. Silva et al. (2013) claimed that embryo size is a characteristic that may be related to the performance of the seeds and may be defined in relation to the available space in the internal cavity of the seeds. Therefore, these seeds may have immature embryos, which would explain the lack of germination.

The identification of filled, empty, or malformed seeds of Lychnophora pinaster Mart., Asteraceae (arnica) by the use of images was also efficient to classify viable seeds, suggesting that the use of this technique can be more effective than the use of blowers in seed processing (Melo et al., 2009).

For seeds that presented some kind of damage in their structure (Figure 3A), we confirm that when the damage was present in the embryo, no germination occurred; however, when the damage was in the endosperm areas,

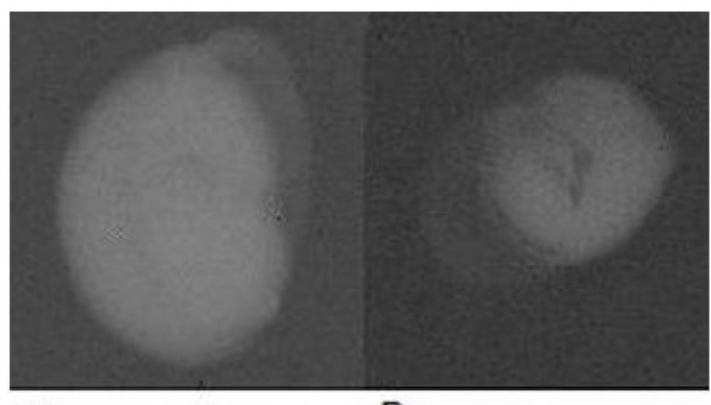

A

B

Figure 2. Campomanesia pubescens seeds with malformations. (A) Small malformation; (B) Malformation close to $50 \%$ of the total seed.

Table 1. Percentage of Campomanesia pubescens (DC.) O. Berg (Myrtaceae) seeds subjected to the X-ray test and classified into pre-established classes within the different water content treatments.

\begin{tabular}{crrrrr}
\hline \multirow{2}{*}{ Classes } & \multicolumn{5}{c}{ Water content } \\
\cline { 2 - 5 } & $\mathbf{2 8 \%}$ & $\mathbf{3 1 \%}$ & $\mathbf{3 4 \%}$ & $\mathbf{3 7 \%}$ & $\mathbf{4 3 \%}$ \\
\hline $\mathbf{A}$ & $43.96 \mathrm{Db}$ & $72.22 \mathrm{Ba}$ & $74.00 \mathrm{Aa}$ & $64.50 \mathrm{Ca}$ & $74.26 \mathrm{Aa}$ \\
$\mathbf{B}$ & $53.30 \mathrm{Aa}$ & $20.71 \mathrm{Db}$ & $21.50 \mathrm{Db}$ & $32.50 \mathrm{Bb}$ & $24.26 \mathrm{Cb}$ \\
$\mathbf{C}$ & $2.20 \mathrm{Cc}$ & $5.05 \mathrm{Ac}$ & $4.00 \mathrm{ABc}$ & $2.50 \mathrm{BCc}$ & $0.99 \mathrm{Cc}$ \\
$\mathbf{D}$ & $0.55 \mathrm{Ac}$ & $2.02 \mathrm{Ad}$ & $0.50 \mathrm{Ad}$ & $0.50 \mathrm{Ad}$ & $0.50 \mathrm{Ac}$ \\
\hline
\end{tabular}

Filled seeds (A); malformed seeds (B); damaged seeds (C); and empty seeds (D). Averages followed by the same capital letters horizontally, and lower case letters vertically, do not differ statistically.

Table 2. Percentage of germinated seeds of Campomanesia pubescens (DC.) O. Berg (Myrtaceae), with different water content subjected to the X-ray test and classified according to pre-established classes.

\begin{tabular}{cccccc}
\hline \multirow{2}{*}{ Classes } & \multicolumn{5}{c}{ Water content } \\
\cline { 2 - 6 } & $\mathbf{2 8 \%}$ & $\mathbf{3 1 \%}$ & $\mathbf{3 4 \%}$ & $\mathbf{3 7 \%}$ & $\mathbf{4 3 \%}$ \\
\hline $\mathbf{A}$ & $29.00 \mathrm{~Eb}$ & $64.50 \mathrm{Ba}$ & $54.50 \mathrm{Ca}$ & $35.50 \mathrm{Da}$ & $71.00 \mathrm{Aa}$ \\
$\mathbf{B}$ & $32.50 \mathrm{Aa}$ & $13.50 \mathrm{Bb}$ & $10.00 \mathrm{CDb}$ & $10.50 \mathrm{CDb}$ & $12.00 \mathrm{BCb}$ \\
$\mathbf{C}$ & $1.50 \mathrm{Ac}$ & $1.00 \mathrm{Ac}$ & $0.50 \mathrm{Ac}$ & $1.00 \mathrm{Ac}$ & $0.00 \mathrm{Ac}$ \\
$\mathbf{D}$ & $0.00 \mathrm{Ac}$ & $0.00 \mathrm{Ac}$ & $0.00 \mathrm{Ac}$ & $0.00 \mathrm{Ac}$ & $0.00 \mathrm{Ac}$ \\
\hline
\end{tabular}

Filled seeds (A); malformed seeds (B); damaged seeds (C); and empty seeds (D). Averages followed by the same capital letters horizontally, and lower case letters vertically, do not differ statistically. 


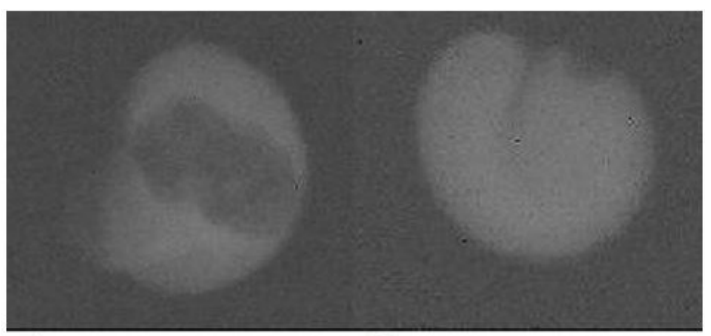

A

B

Figure 3. Campomanesia pubescens seed with damage to its structure. (A) Damage in the seed embryo; (B) Damage in the seed endosperm.

that is, in the tissue with a nutritional reserve, the seed could germinate (Figure 3B). For the empty seeds, no germination occurred, as expected, because they had no embryo or endosperm.

Carvalho et al. (2010) also found a low percentage of germination in seeds with deformations in the embryo and no germination for empty seeds, reinforcing the hypothesis that damage to the embryo is lethal, and as such, these seeds should be discarded.

\section{Conclusion}

The X-ray test was efficient in the identification of filled, malformed, damaged and empty seeds, which germination rate above $50 \%$ in the filled seeds. This visualization of the internal morphology of the seed can be useful to select seeds of better quality, improving the percentage of germination of $C$. pubescens seeds.

The drying of $C$. pubescens seeds, with different water content, might influence the internal structure and the germination of the seeds.

\section{Acknowledgements}

The authors would like to thank the Federal Institute of Education, Science and Technology Goiano for providing financial support. Are grateful to the Coordination for the Improvement of Higher Education Personnel (CAPES).

\section{References}

AMARAL, J.B., MARTINS, L., FORTI, V.A., CÍCERO, S.M. and MARCOS FILHO, J., 2011. Teste de raios X para avaliação do potencial fisiológico de sementes de ipê-roxo. Revista Brasileira de Sementes, vol. 33, no. 4, pp. 601-607. http://dx.doi.org/10.1590/ S0101-31222011000400001.

BARBEDO, C.J., BILIA, D.A.C. and FIGUEIREDO-RIBEIRO, R.C.L., 2002. Tolerância à dessecação e armazenamento de sementes de Caesalpinia echinata Lam. (pau-brasil), espécie da Mata Atlântica. Brazilian Journal of Botany, vol. 25, no. 4, pp. 431-439. http://dx.doi.org/10.1590/S0100-84042002012000007.

BRASIL. Ministério da Agricultura Pecuária e Abastecimento, 2009. Regras para análise de sementes. Brasília: MAPA.
CARMONA, R., REZENDE, L.P. and PARENTE, T.V., 1994. Extração química de sementes de gabiroba (Campomanesia adamantium Camb.). Revista Brasileira de Sementes, vol. 16, no. 1, pp. 31-33. http://dx.doi.org/10.17801/0101-3122/rbs. v16n1p31-33.

CARVALHO, M.L.M., ALVES, R.A. and OLIVEIRA, L.M., 2010. Radiographic analysis in castor bean seeds (Ricinus communis L.). Revista Brasileira de Sementes, vol. 32, no. 1, pp. 170-175. http://dx.doi.org/10.1590/S0101-31222010000100019.

CARVALHO, M.L.M., SILVA, C.D., OLIVEIRA, L.M., SILVA, D.G. and CALDEIRA, C.M., 2009. Teste de raios X na avaliação da qualidade de sementes de abóbora. Revista Brasileira de Sementes, vol. 31, no. 2, pp. 221-227. http://dx.doi.org/10.1590/ S0101-31222009000200026.

COTA, L.G., MOREIRA, P.A., MENEZES, E.V., GOMES, A.S., ERICSSON, A.R.O., OLIVEIRA, D.A. and MELOJUNIOR, A.F., 2012. Transferability and characterization of simple sequence repeat markers from Anacardium occidentale to A. humile (Anacardiaceae). Genetics and Molecular Research, vol. 11, no. 4, pp. 4609-4616. http://dx.doi.org/10.4238/2012. October.17.7. PMid:23096925.

CRUZ, C.D., 2013. GENES: a software package for analysis in experimental statistics and quantitative genetics. Acta Scientiarum: Agronomy, vol. 35, no. 3, pp. 271-276. http://dx.doi.org/10.4025/ actasciagron.v35i3.21251.

DOUSSEAU, S., ALVARENGA, A.A., GUIMARÃES, R.M., LARA, T.S., CUSTÓDIO, T.N. and CHAVES, I.S., 2011. Ecofisiologia da germinação de sementes de Campomanesia pubescens. Ciência Rural, vol. 41, no. 8, pp. 1362-1368. http:// dx.doi.org/10.1590/S0103-84782011000800011.

DRESCH, D.M., SCALON, S.P.Q., MASETTO, T.E. and VIEIRA, M.C., 2012. Germinação de sementes de Campomanesia adamantium (Camb.) O. Berg em diferentes temperaturas e umidades do subtrato. Scientia Forestalis, vol. 40, no. 94, pp. 223-229.

GARAY, A., ELIAS, S.G. and MEYER, D.J.L., 2009. Seed tesyting international. Zurich: International Seed Testing Association. ISTA News Bulletin, no. 138.

GOGOSZ, A.M., BONA, C., SANTOS, G.O. and BOTOSSO, P.C., 2010. Germination and initial growth of Campomanesia xanthocarpa O. Berg. (Myrtaceae), in petroleum-contaminated soil and bioremediated soil. Brazilian Journal of Biology $=$ Revista Brasileira de Biologia, vol. 70, no. 4, pp. 977-986. http://dx.doi. org/10.1590/S1519-69842010000500009. PMid:21180902.

LIMA, L.K.S., DUTRA, A.S., SANTOS, C.C. and BARROS, G.L., 2013. Utilização de técnicas na avaliação de sementes por imagem. Acsa, vol. 9, no. 3, pp. 1-6.

MARCOS FILHO, J., 2005. Fisiologia de sementes de plantas cultivadas. Piracicaba: FEALQ.

MARTINS, W.A., MANTELLI, M., SANTOS, S.C., COSTA NETTO, A.P. and PINTO, F., 2015. Estaquia e concentração de reguladores vegetais no enraizamento de Campomanesia adamantium. Revista de Ciências Agrárias, vol. 38, no. 1, pp. 58-64.

MASETTO, T.E., DAVIDE, A.C., SILVA, E.A.A. and FARIA, J.M.R., 2007. Avaliação da qualidade de sementes de Eugenia pleurantha (Myrtaceae) pelo teste de raios X. Revista Brasileira de Sementes, vol. 29, no. 3, pp. 170-174. http://dx.doi.org/10.1590/ S0101-31222007000300020.

MELCHIOR, S.J., CUSTÓDIO, C.C., MARQUES, T.A. and MACHADO-NETO, N.B., 2006. Colheita e armazenamento 
de sementes de gabiroba (Campomanesia adamantium Camb. Myrtaceae) e implicações na germinação. Revista Brasileira de Sementes, vol. 28, no. 3, pp. 141-150. http://dx.doi.org/10.1590/ S0101-31222006000300021.

MELO, P.R.B., OLIVEIRA, J.A., CARVALHO, M.L.M., GUIMARÃES, R.M. and CARVALHO, B.O., 2009. Aplicação do teste de raios $\mathrm{X}$ no estudo da morfologia interna e da qualidade fisiológica de aquênios de arnica (Lychnophora pinaster Mart.). Revista Brasileira de Sementes, vol. 31, no. 2, pp. 146-154. http:// dx.doi.org/10.1590/S0101-31222009000200017.

MUXFELDT, R.E., FARIA, J.M.R., TONETTI, O.A.O. and SILVA, E.A.A., 2012. Utilização do teste de raios X na avaliação dos efeitos da dessecação e infestação em diásporos de canelabatalha - Cryptocarya aschersoniana Mez (Lauraceae). Cerne, vol. 18 , no. 4 , pp. 657-666. http://dx.doi.org/10.1590/S010477602012000400016 .

NUNES, R.T.C., SOUZA, U.O., MORAIS, O.M. and LOURENÇO, C.M.S., 2014 [viewed 14 February 2019]. Análise de imagens na avaliação da qualidade fisiológica de sementes. Revista Verde de Agroecologia e Desenvolvimento Sustentável [online], vol. 9, no. 5, pp. 84-90. Available from: http://www.gvaa.com.br/revista/ index.php/RVADS/article/view/3339

PINTO, T.L.F., MONDO, V.H.V., GOMES-JÚNIOR, F.G. and CÍCERO, S.M., 2012. Análise de imagens na avaliação de danos mecânicos em sementes de soja. Pesquisa Agropecuária Tropical, vol. 42, no. 3, pp. 310-316. http://dx.doi.org/10.1590/ S1983-40632012000300010.
SANTOS, C.M.R., FERREIRA, A.G. and ÁQUILA, M.E.A., 2004. Características de frutos e germinação de sementes de seis espécies de Myrtaceae nativas do Rio Grande do Sul. Ciência Florestal, vol. 14, no. 2, pp. 13-20. http://dx.doi. org/10.5902/198050981802.

SCALON, S.P.Q., LIMA, A.A., SCALON FILHO, H. and VIEIRA, M.C., 2009. Germinação de sementes e crescimento inicial de mudas de Campomanesia adamantium Camb.: efeito da lavagem, temperatura e de bioestimulantes. Revista Brasileira de Sementes, vol. 31, no. 2, pp. 96-103. http://dx.doi.org/10.1590/ S0101-31222009000200011.

SILVA, V.N., SARMENTO, M.B., SILVEIRA, A.C., SILVA, C.S. and CICERO, S.M., 2013. Avaliação da morfologia interna de sementes de Acca selowiana O. Berg por meio de análise de imagens. Revista Brasileira de Fruticultura, vol. 35, no. 4, pp. 1158-1169. http://dx.doi.org/10.1590/S0100-29452013000400027.

SOBRAL, M., PROENÇA, C., SOUZA, M., MAZINE, F. and LUCAS, E., 2015 [viewed 14 February 2019]. Myrtaceae. In: JARDIM BOTÂNICO DO RIO DE JANEIRO. Lista de espécies da flora do Brasil [online]. Rio de Janeiro: JBRJ. Available from: http://floradobrasil.jbrj.gov.br/jabot/floradobrasil/FB10307

VAN DER BURG, W.J., AARTSE, J.W., VAN ZWOL, R.A., JALINK, H. and BINO, R.J., 1994. Predicting tomato seedling morphology by X-ray analysis of seeds. Journal of the American Society for Horticultural Science, vol. 119, no. 2, pp. 258-263. http://dx.doi.org/10.21273/JASHS.119.2.258. 